\title{
Implementing Brazil's Forest Code: a vital contribution to securing forests and conserving biodiversity
}

\author{
Rebecca Catherine Brock ${ }^{1}$ (D) Andy Arnell ${ }^{1}$ (D) Will Simonson ${ }^{1}$ (D) \\ Aline C. Soterroni ${ }^{2,3}$ (D) Aline Mosnier ${ }^{2}$ (D) Fernando Ramos ${ }^{3}$ (D) . \\ Alexandre Xavier Ywata de Carvalho ${ }^{4}$. Gilberto Camara ${ }^{3}$ (D) . Johannes Pirker ${ }^{2}$ D . \\ Michael Obersteiner ${ }^{2}$ (D) . Valerie $\operatorname{Kapos}^{1}$ (D)
}

Received: 16 September 2020 / Revised: 7 February 2021 / Accepted: 9 March 2021 /

Published online: 3 April 2021

(c) The Author(s) 2021

\begin{abstract}
Meeting Brazil's ambitious national commitments on both climate change mitigation and biodiversity conservation depends on securing its reserves of forest carbon and biodiversity. Brazil's 'Forest Code' is a key tool to reconcile environmental preservation and agricultural production; it limits deforestation and requires forest restoration in illegally deforested areas. However, not all provisions of the law's 2012 revision have yet been implemented and some are facing new challenges. Using modelled land use change projections for the whole of the country, we show that full implementation and enforcement of the law has the potential to contribute to conserving biodiversity. Biodiversity outcomes will be especially positive if (i) deforested areas are restored in ways that support recolonization by native species and (ii) additional measures are implemented to protect native vegetation in areas like Caatinga dry forests and Cerrado savannas, which may experience added pressure displaced from other regions by Forest Code implementation.
\end{abstract}

Keywords Biodiversity · Brazil · Conservation · Deforestation · Forest carbon · Forest code $\cdot$ Land use modelling $\cdot$ Restoration $\cdot$ Threatened species

Communicated by Pedro V. Eisenlohr.

This article belongs to the Topical Collection: Forest and plantation biodiversity.

Rebecca Catherine Brock

Rebecca.mant@cantab.net

1 United Nations Environment Programme World Conservation Monitoring Centre, Cambridge, UK

2 International Institute for Applied Systems Analysis, Laxenburg, Austria

3 National Institute for Space Research, São José dos Campos, Brazil

4 Institute of Applied Economic Research, Brasília, Brazil 


\section{Introduction}

As a mega-diverse country, with two of the world's biodiversity hotspots (Myers et al. 2000) and the world's largest remaining expanse of tropical rain forest, Brazil has helped to set global objectives on halting biodiversity loss. However, many Brazilian species and ecosystems are under increasing pressure, with agricultural expansion and related land use change being major threats here (de Mello et al. 2015; Moura et al. 2013; de Castro Solar et al. 2016), as they are globally (Newbold et al. 2015). In 2019 annual rates of deforestation in the Amazon reached their highest level in a decade (PRODES 2019). Although the majority of land owners abide by deforestation laws, not all do and this contributes to the overall rate of deforestation (Rajão et al. 2020).

Brazil's national biodiversity targets, which mirror the Convention on Biological Diversity's Aichi targets, aim to address the underlying causes of biodiversity loss, reduce direct pressures on biodiversity, promote sustainable use, and improve the status of biodiversity (MMA 2016). The national targets to be achieved by 2020 include significantly reducing the risk of extinction of threatened species (target 12) and at least halving the rate of loss of native habitats (relative to 2009 rates; target 5; MMA 2016).

Brazil has also set ambitious objectives for contributing to climate change mitigation by reducing land-use related and other greenhouse gas emissions. Its nationally determined contribution (NDC) to achieving the goals of the Paris Agreement includes policies and measures for achieving zero illegal deforestation in the Brazilian Amazon by 2030 (Federative Republic of Brazil 2015).

Given anticipated increases in population size, demand for agricultural goods (OECD/ FAO 2016), and pressure for agricultural expansion, meeting these biodiversity conservation and climate change mitigation objectives requires effective design, implementation and enforcement of policies, laws and regulations. Brazil's main tool for regulating land use change on private lands is the Natural Vegetation Protection act, (Law n ${ }^{\circ} 12,651$, commonly known as the 'Forest Code', FC), which was revised in 2012 and establishes regionspecific legal limits to the amount of deforestation that can occur on a private property (Table 1). Growing pressures and threats to Brazil's fauna triggered the Brazilian government to list those species facing the highest degree of threat, and work to develop conservation action plans and strategies for all listed species (MMA 2016). However, recently, Brazil's government has decreased environmental protections (Rochedo et al. 2018).

Making good decisions on the design, implementation and enforcement of policies, laws and regulations, requires clear understanding of potential risks, benefits and trade-offs.

Table 1 Main provisions within the revised 'Forest Code'

\begin{tabular}{ll}
\hline Provision & Details \\
\hline Legal reserves & $\begin{array}{c}\text { The minimum percentage of forest which needs to be preserved on every } \\
\text { private property. It varies across Brazil's six biomes ranging from } 80 \% \text { in } \\
\text { the Amazon biome to } 20 \% \text { in the Atlantic Forest and Caatinga, and it also } \\
\text { designates environmentally sensitive areas, such as riversides and hilltops, } \\
\text { as areas of permanent preservation }\end{array}$ \\
$\begin{array}{l}\text { Obligations for restoration } \\
\text { Anvironmental reserve quo- } \\
\text { tas mechanism (CRA) }\end{array}$ & $\begin{array}{c}\text { The CRA mechanism allows landowners to 'trade' reforestation requirements } \\
\text { for preservation of mature forest elsewhere in the same biome (see SI) }\end{array}$ \\
\hline
\end{tabular}


Previous modelling studies (e.g. Soares-Filho et al. 2014; Soterroni et al. 2018) and reviews (Brancalion et al. 2016) have explored the potential impacts of the effective implementation of the FC on land use change, or the impact of land use change on Brazilian species (SoaresFilho et al. 2006; Bird et al. 2012; Strassburg et al. 2012; de Castro Solar et al. 2016). Other studies have assessed the impact of the FC on biodiversity in particular biomes (Brandão et al. 2020; Strassburg et al. 2017; Vieira et al. 2018). However, comprehensively determining the potential contribution of FC implementation and enforcement to achieving conservation targets for threatened species, and any potential trade-offs between the impacts on different biomes and targets, requires assessing the implications for land use change across all of Brazil and the associated impacts on species. This is especially true for biomes other than the Amazon, including the Caatinga (Santos et al. 2011) and non-forest ecosystems, which have often been omitted from previous assessments (Overbeck et al. 2015). Furthermore, since the annual rate of deforestation in the Amazon has been increasing since 2012 (PRODES 2019), and there have been recent reductions in environmental regulations (Rochedo et al. 2018), we urgently need to assess and compare the potential risks of not fully implementing or enforcing the provisions of the FC with the benefits of doing so.

To this end, we are using the GLOBIOM-Brazil model (Soterroni et al. 2018; Soterroni et al. 2019) a regional version of the global land use partial equilibrium model GLOBIOM (Havlík et al. 2011, 2014). GLOBIOM-Brazil simulates the competition for land among the main sectors of the land use economy (agriculture, forestry and bioenergy) by maximizing the sum of consumer and producer surpluses subjected to resource, technology and policy restrictions. The demand is driven by gross domestic product (GDP) and population growth, and dietary trends derived from the Shared Socioeconomic Pathways (SSPs) (O'Neill et al. 2014). On the supply side, production is endogenously adjusted to meet the demand for all 30 regions represented in the model, including Brazil. As a result of the maximization of the welfare, the equilibrium quantities and prices are obtained for each region and product. The model projects the extent and spatial distribution of land use change that these demands for agricultural goods may result in. It allows changes between all different land uses (e.g. pasture to agriculture, and forest to pasture) in order to meet the agricultural demands in the most economically efficient way. GLOBIOM-Brazil reflects Brazil's specificities and captures the major trends of land use including deforestation and agriculture expansion during the historical period, which gives confidence in the model projections. We used the scenarios from Soterroni et al. 2018 to explore land use changes associated with some of the provisions included in the FC (Table 1), linking this to potential economic, productivity and emissions impacts. These scenarios show the effect of the different provisions of the forest code by imposing or relaxing restrictions on land use transitions. Here, we assess the potential impacts on biodiversity of Soterroni's GLOBIOM-Brazil land use change projections across the country's 6 terrestrial biomes and in relation to priority areas for biodiversity conservation. We show where projected land use change threatens biodiversity and highlight the relative impacts of different provisions included in the FC.

\section{Methods}

\section{Land use change model}

We used GLOBIOM-Brazil, a bottom-up recursive dynamic global partial equilibrium economic model, to project land use change from the baseline year 2000 up to 2050 (Soterroni 
et al. 2018; Soterroni et al. 2019; Uba de Andrade Junior et al. 2019; Zilli et al. 2020). The model runs in 10 year timesteps and takes into account projected changes in population and demands for goods (both nationally and globally), as well as spatially-varying factors such as land productivity, production costs, and internal transportation costs, to simulate the production and trade of 18 crops, 5 forestry products and 7 livestock products on uniform grid with a spatial resolution of approximately $50 \mathrm{~km}$ by $50 \mathrm{~km}$ at the equator for Brazil, and $200 \mathrm{~km}$ by $200 \mathrm{~km}$ for the rest of the world. It produces projections of land use as the proportion of each gridcell covered by each of 6 land use classes (Table 2). The model allows for land use displacement, since if land use conversion is restricted in one area the demand will shift to other areas. It also allows for the indirect effect of agricultural expansion, since where projections suggest the most economically efficient use of existing pasture is conversion to cropland, demand for livestock products will be met elsewhere.

\section{Policy scenarios}

We used the GLOBIOM-Brazil model to simulate policy scenarios exploring the impact of different components of the FC. The policy scenarios ranged from no implementation of the FC to full implementation and enforcement (Table 3). The No_FC scenario simulates the potential deforestation if no provisions of the FC are enforced. This scenario therefore simulates control of deforestation beyond legal limits only for the Atlantic Forest biome, where specific restrictive legislation distinct from the FC, "Law 11.428/2006" also known as the Atlantic Forest Law, has been in place since 2006. The FC scenario covers the full implementation and enforcement of all the main provisions of the 2012 FC regulations, thus assuming there is zero illegal deforestation in all biomes after 2010, and full compliance with the forest restoration obligation and implementation of the environmental reserve quotas mechanism (CRA; Table 1) after 2020. Note that legal deforestation of forest surpluses is allowed at all times.

A set of intermediate policy scenarios explored the impact of enforcing deforestation restrictions without considering the potentially confounding influence of restoration requirements (i.e. in these scenarios varying deforestation restrictions were enforced but the restoration requirements were not). These scenarios are where illegal deforestation is controlled only in the Amazon and Atlantic Forest (IDC_Amazon), or everywhere in Brazil

Table 2 Land use categories used in the Globiom Brazil model

\begin{tabular}{|c|c|}
\hline Category & Details \\
\hline 'Unmanaged forest' & $\begin{array}{l}\text { Forest (including evergreen rainforest of the Amazon, deciduous forest of the } \\
\text { Caatinga and woody savannas of the Cerrado) that was present in } 2000 \text { and not } \\
\text { used for production according to the input data (IBGE Vegetation Map, SOS Mata } \\
\text { Atlantica forest map, and MODIS) }\end{array}$ \\
\hline 'Managed forest' & $\begin{array}{l}\text { Forest that was present in } 2000 \text { and is used for timber production according to these } \\
\text { sources }\end{array}$ \\
\hline 'Forest regrowth' & $\begin{array}{l}\text { Areas that are set aside due to enforcement of the requirements to restore illegally } \\
\text { deforested area under the FC }\end{array}$ \\
\hline 'Other natural land' & $\begin{array}{l}\text { Land not in productive use, mosaics of natural vegetation and areas previously used } \\
\text { for agriculture but not currently under production }\end{array}$ \\
\hline Cropland & Initial distribution defined according to national agricultural census data \\
\hline Pasture & Initial distribution defined according to national agricultural census data \\
\hline
\end{tabular}




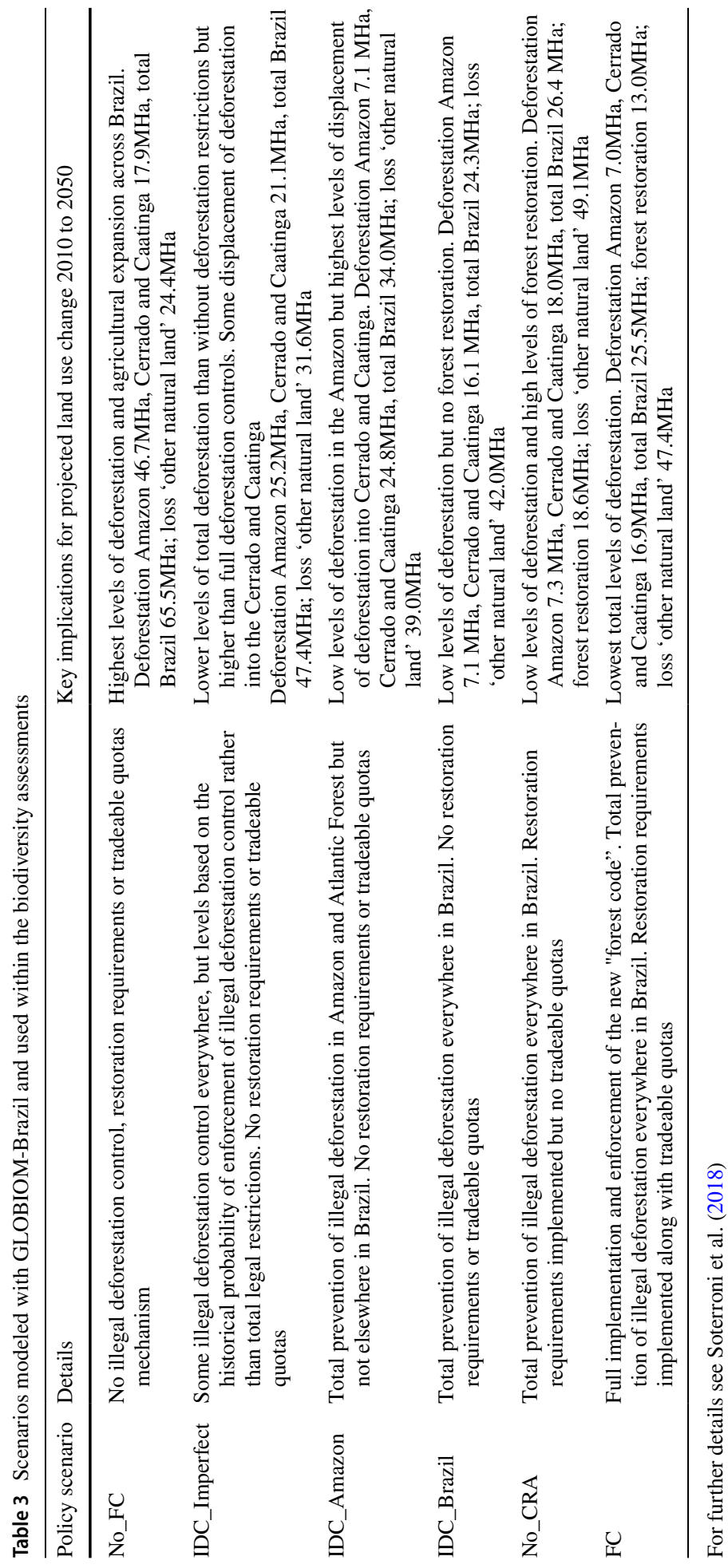


(IDC_Brazil), or where there is imperfect illegal deforestation control (IDC_Imperfect). In the latter, the historical probability of enforcement of illegal deforestation control, p, was calculated per grid cell and deforestation restricted to a proportion of each grid cell equal to $1.5 \mathrm{p}$ (see Soterroni et al. 2018). In a final scenario (No_CRA), all FC provisions are implemented and enforced except the CRA, to explore the influence of this mechanism. The environmental debts are based on the Cadastro Ambiental Rural (the Rural Environmental Registry-CAR) information (Guidotti et al. 2017), which differentiates between permanent preservation areas (APP) and legal reserve (LR) areas. In the FC scenario, the model fully repays the APP debts through restoration, and only the LR debts are subjected to compensation through the CRA mechanism (see Soterroni et al. 2018).

\section{Biodiversity impacts}

We assessed the potential impacts of the projected land use changes on (i) species and (ii) priority areas for biodiversity conservation defined by the Environment Ministry (MMA; MMA 2007).

\section{Species}

We assessed the impacts of modelled land use change on the 311 species (mammals, amphibians and birds) identified by the Brazilian government as threatened, for which data on extent of occurrence (range) were available from the IUCN Red List (IUCN 2013) (see SI Table S1 for the list of species). The assessment built on the impact score approach used by Buchanan et al. (2011). The main indicator we used was an assessment for each species of the likely change in the amount of suitable habitat along with the proportion of suitable habitat lost or gained between 2010 and 2050. The identification of suitable habitat for each species was based on a cross-walk between IUCN habitat classes and the GLOBIOM land use categories (SI Table S2). The impacts of land use change were assessed by calculating loss or gain in the potential habitat the land use change represents. GLOBIOMBrazil works in $50 \mathrm{~km}$ by $50 \mathrm{~km}$ cells but the species range data are at a finer resolution. Thus, in combining the two datasets we assumed that suitable habitat from the model had the maximum overlap with species ranges in 2010 , i.e. that if $30 \%$ of a grid-cell contained suitable habitat in 2010 and a species range covered $40 \%$ of the grid-cell we assumed that all of the suitable habitat occurred within the species range. We assumed that land use change to 2050 in a grid-cell was evenly distributed.

\section{Priority areas}

The Brazilian ministry of the environment, MMA, has identified areas of priority for biodiversity conservation (Rosa et al. 2007). Many of the areas identified as national priorities for biodiversity are under legal protection (e.g. are within National Parks). Since GLOBIOM-Brazil assumes these protected areas prevent land use change, we focussed our assessment on the impacts of projected land use change on biodiversity priority areas that are outside protected areas. As with the species assessment, the modelled land use change in biodiversity priority areas was assessed by assuming that different land classes in a gridcell are evenly distributed. (For both species and priority areas, the effects of this assumption were tested; see SI). 


\section{Results}

\section{Impact of the forest code and preventing illegal deforestation}

Comparing $F C$ and $N o \_F C$ scenarios, full implementation and enforcement of the FC (including both its deforestation restrictions and restoration requirements, as well as tradeable quotas) is projected to lead to many fewer species losing habitat and many more species gaining habitat between 2010 and 2050 (Fig. 1). Preventing illegal deforestation across Brazil (IDC_Brazil) on its own (i.e. without the restoration requirements or tradeable quotas within the FC) reduces by more than a quarter the number of species projected to lose over 5\% of their habitat 2010-2050 compared to a scenario without the Forest Code, where illegal deforestation is prevented only in the Atlantic Forest (No_FC; Fig. 1). As expected, if illegal deforestation controls are not fully enforced (IDC_Imperfect) more species lose over 5\% of their habitat than if there is full enforcement (IDC_Brazil). However, this partial enforcement does reduce the number of species losing over 30\% and over 5\% of their habitat compared to no enforcement (No_FC). Preventing illegal deforestation only in the Amazon (IDC_Amazon) leads to more species losing habitat compared to the scenario in which illegal deforestation is prevented across the whole of Brazil (IDC_Brazil). It is also worth noting that preventing illegal deforestation across the country decreases the number of species gaining habitat due to a net reduction in the area of 'other natural land', land not in productive use: abandoned agricultural land is brought back into production, and other native vegetation remnants are lost (see Table 1 for definition). Crucially, even with full implementation and enforcement of the FC a number of species are still projected to lose a large proportion of their habitat.

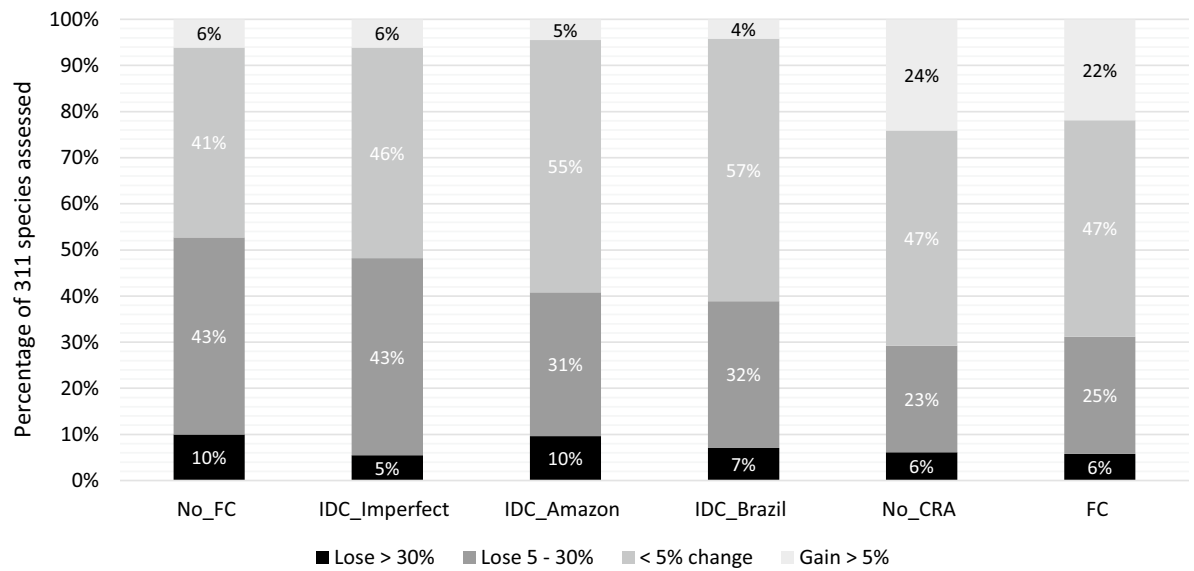

Fig. 1 The proportion of 311 assessed species which lose (or gain) different percentages of their potential habitat between 2010 and 2050 under each scenario, assuming that species can re-colonise regenerating forest. Scenarios: No_FC_no implementation of the "Forest Code"; IDC_Imperfect-imperfect illegal deforestation control everywhere; IDC_Amazon-prevention of illegal deforestation in the Amazon and Atlantic Forest; IDC_Brazil_-prevention of illegal deforestation across Brazil; No_CRA-implementation of deforestation controls and restoration requirements within the "Forest Code" but no tradeable quotas; and $F C$ full implementation and enforcement of the new "Forest Code" 


\section{Impacts of FC restoration and tradeable quota provisions}

Including the restoration provision of the forest code enables some species to gain habitat, whether or not the CRA mechanism is included (Fig. 2). However, the impacts depend on the suitability of restored forest as habitat and the ability of species to recolonise it. If areas set aside to meet the forest restoration requirements are not suitable for species recolonization, the number of species with projected net loss of habitat is much higher and the number of species gaining habitat is much lower than under the optimistic assumption that regenerating forest will be recolonised by forest species. Compared to the full FC, the removal of the CRA mechanism (No_CRA) increases deforestation and decreases the amount of 'other natural land' in unprotected biodiversity priority areas (Fig. 3).

\section{Regional variations in the impact of the forest code}

The impacts of the FC are primarily due to a great reduction in the loss of unmanaged forest (from 69Mha $\left[\mathrm{No}_{-} F \mathrm{C}\right]$ to $25 \mathrm{Mha}[F C]$ ) and a gain in regenerating forest (from $0 \mathrm{Mha}$ $\left[N o \_F C\right]$ to $13 \mathrm{Mha}[\overline{F C}]$ ), including within unprotected biodiversity priority areas (Fig. 3). However, there is substantial variation regionally and among biomes in the impacts of land use change on unprotected priority areas under the different scenarios (Fig. 3). The deforestation rate in unprotected biodiversity priority areas within the Caatinga is projected to increase even when illegal deforestation is restricted in all biomes, probably because the limits to deforestation under the FC are less restrictive (higher) in this biome enabling displacement of land uses from other more protected areas. The Pantanal is also at risk of displaced deforestation, with higher deforestation under the FC than without it. No deforestation is projected to occur in the Atlantic Forest in any scenario since the Atlantic forest

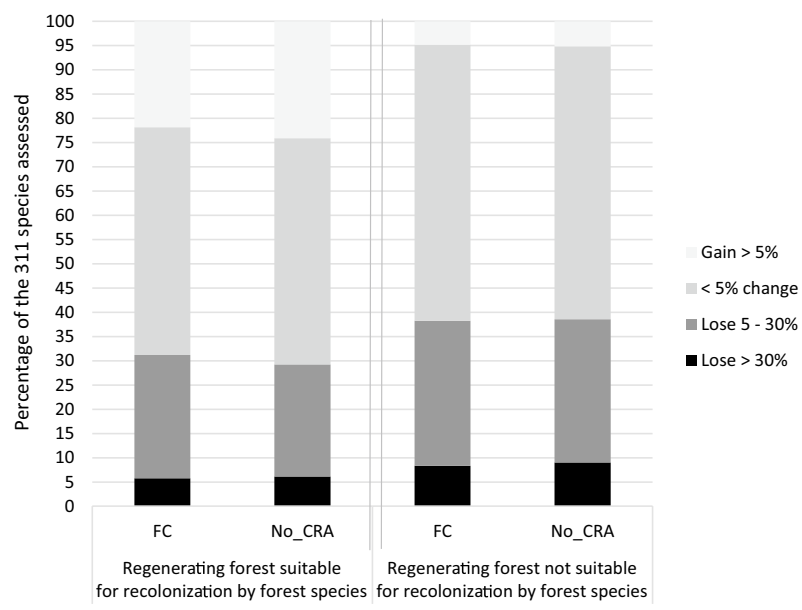

Fig. 2 The potential impact of restoration type on estimated species habitat change under the forest code. The bars present the proportion of species that lose /gain potential habitat between 2010 and 2050 under the assumption that species can re-colonise regenerating forest (left two bars), or the assumption that species cannot re-colonise regenerating forest by 2050 (right two bars). Under each recolonization assumption results are presented for the FC policy scenario, with full implementation and enforcement of the new 'forest code' (left) and No_CRA policy scenario where there is implementation of the deforestation controls and restoration requirements within the 'forest code' but no tradeable quotas (right) 
Percentage of unprotected priority area losing or gaining land cover

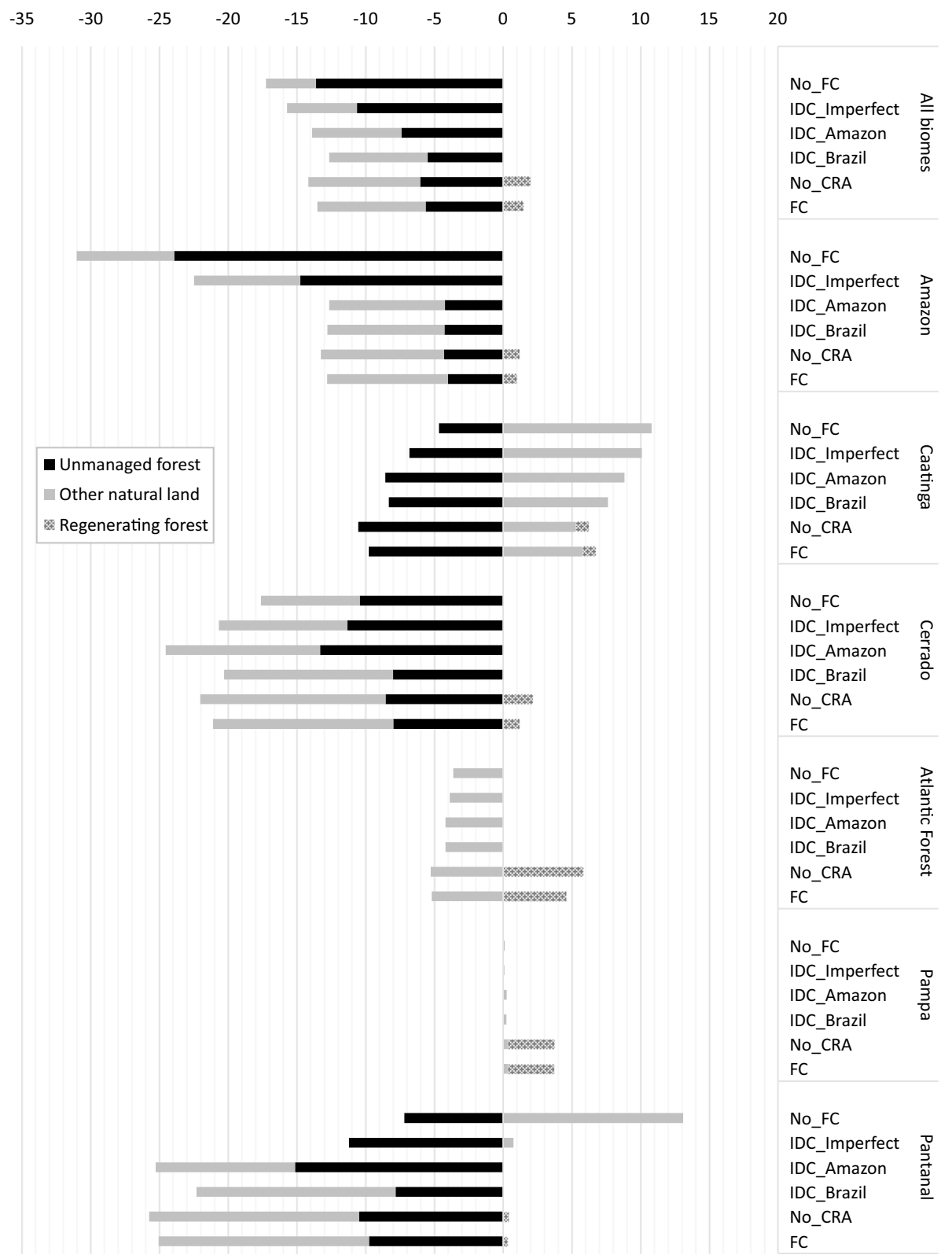

Fig. 3 Land use change within unprotected biodiversity priority areas across different biomes between 2010 and 2050. The bars show the proportion of the total land area over which there is loss of unmanaged forest (black), loss or gain in other natural land (light grey) and gain in regenerating forest (dotted)

is protected under additional legislation to the $\mathrm{FC}$ and so forest loss was not allowed in the model (even in the No_FC scenario). Enforcing prevention of illegal deforestation only in the Amazon and Atlantic Forest does decrease forest loss within biodiversity priority areas 
within the Amazon. However, it is projected to increase deforestation in unprotected biodiversity priority areas in the Caatinga, Cerrado and Pantanal (Fig. 3). Deforestation prevention is also projected to increase conversion of other natural land, especially in the Cerrado and Pantanal (Fig. 3). Projected land-use changes in the Pampa are small in all scenarios.

\section{Discussion}

The FC was enacted to help meet biodiversity conservation, climate change mitigation and sustainable development objectives. Our analysis shows that, on the whole, full implementation and enforcement of the FC would benefit biodiversity by reducing habitat loss for many species and supporting the conservation of forest-dependent biodiversity especially in the Amazon and Cerrado, although other areas may face additional pressures. Effective prevention of illegal deforestation is essential to help achieve the FC goals. Recent deforestation trends most closely follow the imperfect deforestation control policy scenario (IDC_Imperfect, Soterroni et al. 2018). Although the majority of farmers comply with deforestation laws, illegal deforestation does occur with large impacts on total deforestation rates (Rajão et al. 2020). Our results show that increasing enforcement of deforestation restrictions could reduce habitat loss for many species, but also that any further reduction in enforcement greatly increases the risk of more species losing a large proportion of their habitat. With sufficient national and international will and resources, the land registries developed as part of the FC and Brazil's extensive monitoring programmes mean that national public monitoring systems that enforce environmental compliance at property level are possible and could substantially reduce deforestation within Brazil's major supply chains (Rajão et al. 2020). However, further measures beyond the current FC would be needed to prevent ongoing biodiversity loss.

Preventing illegal deforestation did slightly reduce the number of species that gained habitat within the analysis, due to a net reduction in 'other natural land'. However, this result needs to be viewed with caution since the other natural land category of the land use model covers both abandoned agriculture and non-forest natural vegetation. In the assessment of changes in suitable habitat for non-forest species, all of the 'other natural land' that occurred within their potential range was assumed to be suitable for them. This is likely to be an overestimation as many species will be more specialised and take a long time to recolonize abandoned agricultural areas. The impact of the observed increased loss of other natural land within biodiversity priority areas under the FC (compared to the No_FC scenario) will depend on the extent to which agricultural expansion is directed towards abandoned agricultural areas rather than conversion of non-forest native vegetation.

Our analysis highlights the importance of assessing policy impacts across the widest possible scale. The Caatinga, Cerrado and Pantanal are potentially subject to greater impacts from full implementation of the FC than elsewhere in Brazil. The Caatinga and Cerrado biomes have lost substantial amounts of natural vegetation in the past three decades (Beuchle et al. 2015; Strassburg et al. 2017). The GLOBIOM-Brazil projections suggest that such pressure will continue, threatening the biodiversity of non-forest ecosystems (Overbeck et al. 2015; Strassburg et al. 2017). We show that, for biodiversity objectives, discourse on, and effective implementation of, the FC clearly needs to go beyond forests.

The Cerrado biome has the richest flora among the world's savannas ( $>7000$ species) and high levels of endemism (Klink and Machado 2005). The region's fauna depends on the maintenance of its wide range of habitat types (Pacheco and Vasconcelos 2012; 
de Mello et al. 2015). While the model does not differentiate among the more local and specialized habitats, our results suggest that attention to the less-forested Cerrado ecosystems may be warranted, as has been highlighted by other recent studies (Brandão et al. 2020; Durán et al. 2020). The case of the Caatinga is particularly worrisome as little conservation action has so far targeted this biome (Santos et al. 2011). Despite some recognition of the need to increase legal protection (Leal et al. 2005), the proportion of the Caatinga included in protected areas remains low. Although the model limits the agricultural expansion in the Caatinga to its historical trends to take account of water availability constraints (a short and irregular rainy season and propensity to frequent droughts), introduction of irrigation techniques and new agricultural technologies could foster agricultural expansion here. Thus, special provisions may be needed to protect the Caatinga and its endemic biodiversity.

How specific regulations within the FC are implemented is also critical to its biodiversity impact, in particular on how well species colonise areas of regenerating forest. Such areas often support different species and communities compared to primary forests, and it can take up to 300 years for biodiversity to recover when forest regenerates (Liebsch et al. 2008). Therefore, it is unlikely that all species will quickly recolonise reforested areas. Overall, forest regrowth can compensate greenhouse gas emissions from deforestation, but biodiversity loss is not as easily reversed. Techniques that facilitate recovery of natural forest (e.g. soil management, planting native species and maintenance of, and connectivity with, natural remnants) may promote forest species colonization of restored forest (Chazdon 2013). Therefore, efforts at ecological restoration are likely to be essential to maximising the positive biodiversity impacts of the restoration requirements within the FC.

Although the analysis did not identify a large difference in the number of species losing or gaining habitat with the CRA mechanism, it suggests that fast and effective implementation of the CRA (i.e. enabling farmers to reduce their restoration requirements by conserving areas of mature forest in other locations) could protect existing habitats, including high biodiversity forest areas. Our analysis may have underestimated the impact on species of protecting existing habitat due to the resolution of the analysis. The analysis was not able to differentiate between old and new growth forest, nor between abandoned farmland and other natural land, and so is likely to have underestimated the impact of land use change on species which require old growth forest or undisturbed other native vegetation. Future work is needed to explore the likely added benefit to species of prioritising CRA credits in areas of highest biodiversity priority. Additionally, land use planning at smaller scales than that evaluated by GLOBIOM-Brazil (e.g. local watershed) can help maintain biodiversity while meeting production needs (Kennedy et al. 2016).

This model-based assessment addresses only some of the impacts of agriculture and forestry related land use change on biodiversity. The relatively coarse resolution of GLOBIOM-Brazil meant that another important driver, forest fragmentation (Almeida-Gomes et al. 2016), could not be considered, and neither were infrastructure development (Laurance et al. 2015; Lees et al. 2016) or hunting (De Souza and Alves 2014) accounted for. Over the longer term, land use change and other threats are likely to interact with climate change (Brodie et al. 2012), with important implications for Brazilian biodiversity.

While no single specific model or scenario exercise can cover all threats faced by species and ecosystems, models and scenarios are key tools for guiding development and implementation of policies. Like other land use related polices, the FC was developed to help meet a range of objectives. Our work helps in developing a holistic understanding of the potential benefits of fully implementing and enforcing the FC, and the risks of not doing so. 
Overall, the full and effective enforcement of the FC can be good for biodiversity, especially if additional measures are put into place to protect areas such as native vegetation in the Caatinga and Cerrado, which may be under increased pressure due to FC implementation and enforcement elsewhere.

Supplementary Information The online version contains supplementary material available at https://doi. org/10.1007/s10531-021-02159-x.

Acknowledgements This work was supported by the REDD-PAC project (www.redd-pac.org) and the RESTORE+ project (www.restoreplus.org), which are part of the International Climate Initiative (IKI), supported by the Federal Ministry for the Environment, Nature Conservation and Nuclear Safety (BMU) based on a decision adopted by the German Bundestag. To derive the scenarios and help analyse the results, the REDD-PAC team held various rounds of meetings with Brazilian stakeholders. We thank Carlos Klink, Antonio Carlos do Prado, Adriano Oliveira, José Miguez, Carlos Scaramuzza, Francisco Oliveira, and Letícia Guimarães (all MMA), André Nassar (MAPA), Eustáquio Reis (IPEA/MPOG), and Thelma Krug, Dalton Valeriano, Isabel Escada, Silvana Amaral, Luiz Maurano, and Miguel Monteiro (INPE) for advice and guidance.

Funding This work was supported by the REDD-PAC project (www.redd-pac.org) and the RESTORE + project (www.restoreplus.org), which are part of the International Climate Initiative (IKI), supported by the Federal Ministry for the Environment, Nature Conservation and Nuclear Safety (BMU) based on a decision adopted by the German Bundestag.

Data availability The main input and output datafiles from the GLOBIOM-Brazil model are available from www.redd-pac.org. Full data have not been archived according to the BES data archiving policy due to restrictions from the data owners. However, a full list of species used in the analysis are available in the online supplementary material. Species ranges for mammals and amphibians can be downloaded from https://www.iucnredlist.org/resources/spatial-data-download. Bird distribution ranges have to be requested at http://datazone.birdlife.org/species/requestdis. Habitat preferences for vertebrates, including altitudinal ranges, can be downloaded from http://apiv3.iucnredlist.org/api/v3/docs after requesting a token in http:// apiv3.iucnr edlist.org/api/v3/token.

Code availability $\mathrm{R}$ used for the analysis. Explanations of analysis provided in methods but $\mathrm{R}$ code not archived (since no new programmes created).

\section{Declarations}

Conflict of interest The authors have no conflicts of interest to declare that are relevant to the content of this article.

Open Access This article is licensed under a Creative Commons Attribution 4.0 International License, which permits use, sharing, adaptation, distribution and reproduction in any medium or format, as long as you give appropriate credit to the original author(s) and the source, provide a link to the Creative Commons licence, and indicate if changes were made. The images or other third party material in this article are included in the article's Creative Commons licence, unless indicated otherwise in a credit line to the material. If material is not included in the article's Creative Commons licence and your intended use is not permitted by statutory regulation or exceeds the permitted use, you will need to obtain permission directly from the copyright holder. To view a copy of this licence, visit http://creativecommons.org/licenses/by/4.0/.

\section{References}

Almeida-Gomes M, Prevedello JA, Crouzeilles R (2016) The use of native vegetation as a proxy for habitat may overestimate habitat availability in fragmented landscapes. Landscape Ecol 31(4):711-719. https://doi.org/10.1007/s10980-015-0320-3 
Beuchle R, Grecchi RC, Shimabukuro YE, Seliger R, Eva HD, Sano E, Achard F (2015) Land cover changes in the Brazilian Cerrado and Caatinga biomes from 1990 to 2010 based on a systematic remote sensing sampling approach. Appl Geogr 58:116-127. https://doi.org/10.1016/j.apgeog.2015.01.017

Bird JP, Buchanan GM, Lees AC, Clay RP, Develey PF, Yépez I, Butchart SH (2012) Integrating spatially explicit habitat projections into extinction risk assessments: a reassessment of Amazonian avifauna incorporating projected deforestation. Divers Distrib 18(3):273-281. https://doi.org/10.1111/j.14724642.2011.00843.x

Brandão A, Rausch L, Durán AP, Costa C, Spawn SA, Gibbs HK (2020) Estimating the potential for conservation and farming in the Amazon and Cerrado under four policy scenarios. Sustainability 12(3):1277

Brancalion PH, Garcia LC, Loyola R, Rodrigues RR, Pillar VD, Lewinsohn TM (2016) A critical analysis of the Native Vegetation Protection Law of Brazil (2012): updates and ongoing initiatives. Natureza \& Conservação 14:1-15. https://doi.org/10.1016/j.ncon.2016.03.003

Brodie J, Post E, Laurance WF (2012) Climate change and tropical biodiversity: a new focus. Trends Ecol Evol 27(3):145-150. https://doi.org/10.1016/j.tree.2011.09.008

Buchanan GM, Donald PF, Butchart SH (2011) Identifying priority areas for conservation: a global assessment for forest-dependent birds. PloS One. https://doi.org/10.1371/journal.pone.0029080

Chazdon RL (2013) Making tropical succession and landscape reforestation successful. J Sustain Forest 32(7):649-658. https://doi.org/10.1080/10549811.2013.817340

de Castro Solar RR et al (2016) Biodiversity consequences of land-use change and forest disturbance in the Amazon: a multi-scale assessment using ant communities. Biol Cons 197:98-107. https://doi. org/10.1016/j.biocon.2016.03.005

de Souza JB, Alves RRN (2014) Hunting and wildlife use in an Atlantic Forest remnant of northeastern Brazil. Trop Conserv Sci 7(1):145-160. https://doi.org/10.1177/194008291400700105

de Mello PL, Machado RB, Nogueira CDC (2015) Conserving biogeography: Habitat loss and vicariant patterns in endemic squamates of the Cerrado hotspot. PloS One. https://doi.org/10.1371/journal. pone.0133995

Durán AP, Green JM, West CD, Visconti P, Burgess ND, Virah-Sawmy M, Balmford A (2020) A practical approach to measuring the biodiversity impacts of land conversion. Methods Ecol Evol 11:910-921

Federative Republic of Brazil (2015) Intended Nationally Determined Contribution towards achieving the objective of the United Nations Framework Convention on Climate Change. Federative Republic of Brazil, Brasilia

Guidotti V, Freitas F, Sparovek G, Pinto L, Hamamura C, Carvalho T, Cerignoni F (2017) Números detalhados do novo código florestal e suas implicações para os pras. Sustentabilidade em Debate 5:1-11

Havlík P, Schneider UA, Schmid E, Böttcher H, Fritz S, Skalský R, Aoki K, De Cara S, Kindermann G, Kraxner F, Leduc S, McCallum I, Mosnier A, Sauer T, Obersteiner M (2011) Global landuse implications of first and second generation biofuel targets. Energy Policy 39(10):5690-5702. https://doi.org/10.1016/j.enpol.2010.03.030

Havlík P, Valin H, Herrero M, Obersteiner M, Schmid E, Rufino MC, Mosnier A, Thornton PK, Böttcher H, Conant RT, Frank S (2014) Climate change mitigation through livestock system transitions. Proc Natl Acad Sci 111(10):3709-3714

IUCN (2013). The IUCN Red List of Threatened Species. Version 2013.1. http://www.iucnredlist.org. Accessed 1 July 2013

Kennedy CM, Hawthorne PL, Miteva DA, Baumgarten L, Sochi K, Matsumoto M, Evans JS, Polasky S, Hamel P, Vieira EM, Ferreira Develey P, Sekercioglu CH, Davidson AD, Uhlhorn EM, Kiesecker J (2016) Optimizing land use decision-making to sustain Brazilian agricultural profits, biodiversity and ecosystem services. Biol Conserv 204:221-230

Klink CA, Machado RB (2005) Conservation of the Brazilian cerrado. Conserv Biol 19(3):707-713. https://doi.org/10.1111/j.1523-1739.2005.00702.x

Laurance WF, Peletier-Jellema A, Geenen B, Koster H, Verweij P, Van Dijck P et al (2015) Reducing the global environmental impacts of rapid infrastructure expansion. Curr Biol 25(7):R259-R262. https://doi.org/10.1016/j.cub.2015.02.050

Leal IR, Da Silva JMC, Tabarelli M, Lacher TE (2005) Changing the course of biodiversity conservation in the Caatinga of northeastern Brazil. Conserv Biol 19(3):701-706. https://doi.org/10.1111/j. 1523-1739.2005.00703.x

Lees AC, Peres CA, Fearnside PM, Schneider M, Zuanon JA (2016) Hydropower and the future of Amazonian biodiversity. Biodivers Conserv 25(3):451-466. https://doi.org/10.1007/s 10531-016-1072-3

Liebsch D, Marques MC, Goldenberg R (2008) How long does the Atlantic Rain Forest take to recover after a disturbance? changes in species composition and ecological features during secondary succession. Biol Cons 141(6):1717-1725. https://doi.org/10.1016/j.biocon.2008.04.013 
MMA (2007). Priority areas for the conservation, sustainable use and benefit sharing of Brazilian biological diversity. Update: MMA Administrative Ruling $\mathrm{N}^{\circ}$ 9, of 23 January 2007., Ministry of the Environment- MMA, Brasilia, Brazil.

MMA (2016). National Biodiversity Strategy and Action Plan, Ministry of the Environment - MMA, Brasilia

Moura NG, Lees AC, Andretti CB, Davis BJ, Solar RR, Aleixo A et al (2013) Avian biodiversity in multiple-use landscapes of the Brazilian Amazon. Biol Cons 167:339-348. https://doi.org/10.1016/j. biocon.2013.08.023

Myers N, Mittermeier RA, Mittermeier CG, Da Fonseca GA, Kent J (2000) Biodiversity hotspots for conservation priorities. Nature 403(6772):853-858. https://doi.org/10.1038/35002501

Newbold T, Hudson LN, Hill SL, Contu S, Lysenko I, Senior RA et al (2015) Global effects of land use on local terrestrial biodiversity. Nature 520(7545):45-50. https://doi.org/10.1038/nature14324

OECD/FAO (2016). OECD-FAO Agricultural Outlook 2016-2025, OECD Publishing, Paris. Available at: http://dx.doi.org/https://doi.org/10.1787/agr_outlook-2016-en

O’Neill BC, Kriegler E, Riahi K, Ebi KL, Hallegatte S, Carter TR, Mathur R, van Vuuren DP (2014) A new scenario framework for climate change research: the concept of shared socioeconomic pathways. Clim Change 122(3):387-400

Overbeck GE, Vélez-Martin E, Scarano FR, Lewinsohn TM, Fonseca CR, Meyer ST et al (2015) Conservation in Brazil needs to include non-forest ecosystems. Divers Distrib 21(12):1455-1460. https://doi. org/10.1111/ddi.12380

Pacheco R, Vasconcelos HL (2012) Habitat diversity enhances ant diversity in a naturally heterogeneous Brazilian landscape. Biodivers Conserv 21(3):797-809. https://doi.org/10.1007/s10531-011-0221-y

PRODES 2019 Amazon deforestation database (www.obt.inpe.br/prodes). Accessed 6 June 2019

Rajão R, Soares-Filho B, Nunes F, Börner J, Machado L, Assis D, Oliveira A, Pinto L, Ribeiro V, Rausch L, Gibbs H, Figueira D (2020) The rotten apples of Brazil's agribusiness. Science 369(6501):246-248

Rochedo PRR, Soares-Filho B, Schaeffer R, Viola E, Szklo A, Lucena AFP et al (2018) The threat of political bargaining to climate mitigation in Brazil. Nat Clim Chang 8:695-698. https://doi.org/10.1038/ s41558-018-0213-

Rosa M, Albernaz A, Valdujo P, Souza M, Baumgarten L, de Lima LH (2007) Priority areas for the conservation, sustainable use and benefit sharing of Brazilian biological diversity. Technical report, MMA - Brazilian Ministryfor the Environment

Santos JC, Leal IR, Almeida-Cortez JS, Fernandes GW, Tabarelli M (2011) Caatinga: the scientific negligence experienced by a dry tropical forest. Trop Conserv Sci 4(3):276-286. https://doi.org/10.1177/ 194008291100400306

Soares-Filho BS, Nepstad DC, Curran LM, Cerqueira GC, Garcia RA, Ramos CA et al (2006) Modelling conservation in the Amazon basin. Nature 440(7083):520-523. https://doi.org/10.1038/nature04389

Soares-Filho B, Rajão R, Macedo M, Carneiro A, Costa W, Coe M, Rodrigues H, Alencar A (2014) Cracking Brazil's forest code. Science 344(6182):363-364. https://doi.org/10.1126/science.1246663

Soterroni AC, Mosnier A, Carvalho AXY, Camara G, Obersteiner M, Andrade PR, Souza RC, Brock R, Pirker J, Kraxner F, Havlík P (2018) Future environmental and agricultural impacts of Brazil's Forest Code. Environ Res Lett 13:074021. https://doi.org/10.1088/1748-9326/aaccbb

Soterroni AC, Ramos FM, Mosnier A, Fargione J, Andrade PR, Baumgarten L, Pirker J, Obersteiner M, Kraxner F, Câmara G, Carvalho AX (2019) Expanding the soy moratorium to Brazil's Cerrado. Sci Adv. https://doi.org/10.1126/sciadv.aav7336

Strassburg BB, Rodrigues AS, Gusti M, Balmford A, Fritz S, Obersteiner M, Turner RK, Brooks TM (2012) Impacts of incentives to reduce emissions from deforestation on global species extinctions. Nat Clim Chang 2(5):350-355. https://doi.org/10.1038/nclimate1375

Strassburg BB, Brooks TM, Feltran-Barbieri R, Iribarrem A, Crouzeilles R, Loyola R et al (2017) Moment of truth for the Cerrado hotspot. Nat Ecol Evol 1:1-3. https://doi.org/10.1038/s41559-017-0099

de Andrade U, Junior MA, Valin H, Soterroni AC, Ramos FM, Halog A (2019) Exploring future scenarios of ethanol demand in Brazil and their land-use implications. Energy Policy 134:110958. https://doi. org/10.1016/j.enpol.2019.110958

Vieira RRS, Ribeiro BR, Resende FM, Brum FT, Machado N, Sales LP et al (2018) Compliance to Brazil's Forest Code will not protect biodiversity and ecosystem services. Divers Distrib 24:434-438. https:// doi.org/10.1111/ddi.12700

Zilli M, Scarabello M, Soterroni AC, Valin H, Mosnier A, Leclere D, Havlik P, Kraxner F, Lopes MA, Ramos FM (2020) The impact of climate change on Brazil's agriculture. Sci Tot Environ. https://doi. org/10.1016/j.scitotenv.2020.139384 
Publisher's Note Springer Nature remains neutral with regard to jurisdictional claims in published maps and institutional affiliations. 